\title{
Meteorological Interpretation of Orographic Precipitation Gradients along an Andes West Slope Basin at $30^{\circ} \mathrm{S}$ (Elqui Valley, Chile) ${ }^{\mathscr{O}}$
}

\author{
LUCIA SCAFF \\ Global Institute for Water Security, and School of Environment and Sustainability, University of Saskatchewan, \\ Saskatoon, Saskatchewan, Canada \\ Jose A. RutLlant \\ Centro de Estudios Avanzados en Zonas Áridas, La Serena, and Departamento de Geofísica, Facultad de Ciencias \\ Físicas y Matemáticas, Universidad de Chile, Santiago, Chile \\ DAVID RAHN \\ Department of Geography and Atmospheric Science, University of Kansas, Lawrence, Kansas \\ SIMON GASCOIN \\ Centre d'Etudes Spatiales de la Biosphère, CNRS/IRD/UPS/CNES, Toulouse, France \\ ROBERTO RONDANELLI \\ Departamento de Geofísica, Facultad de Ciencias Físicas y Matemáticas, and Center for Climate and Resilience \\ Research, Universidad de Chile, Santiago, Chile
}

(Manuscript received 21 March 2016, in final form 22 November 2016)

\begin{abstract}
To better forecast streamflow and water resource availability, it is important to have an understanding of the meteorological drivers of the orographic precipitation gradient (OPG), especially critical in semiarid mountainous areas. Although forced ascent over topography typically results in precipitation increasing with altitude (positive OPGs), mean annual OPGs and especially OPGs associated with individual storms can change widely in magnitude and even sign. Precipitation measurements from the Elqui Valley in the semiarid Andes of Chile $\left(30^{\circ} \mathrm{S}\right)$ reveal a mean annual OPG of $6.3 \mathrm{~mm} \mathrm{~km}^{-1}$ (millimeters of precipitation over kilometers in elevation) ranging from -42 to $52 \mathrm{~mm} \mathrm{~km}^{-1}$ for individual storms over the last 35 years (19792013). Reanalysis data and precipitation measurements are used to characterize the observed OPG in this region in relation with their synoptic-scale flow. It is found that the Froude number correlates positively with the OPG, reflecting stronger zonal winds and less static stability during storms that have positive OPGs. Altitude of the Andes barrier jet shows only a weak relationship with the OPG. Significant storms with positive OPGs are typically linked with an austral blocking of the westerlies and an equatorward migration of the midlatitude storm track. For negative OPGs, either a cutoff low or the northern edge of a surface migratory cyclone reaches the Elqui Valley in such a way that significant rainfall only occurs in the near-coastal region without major snowfall accumulation over the Andes.
\end{abstract}

Supplemental information related to this paper is available at the Journals Online website: http://dx.doi.org/10.1175/ JHM-D-16-0073.s1.

Corresponding author e-mail: José Rutllant, jrutllan@dgf. uchile.cl

\section{Introduction}

Many semiarid regions rely on mountain "water towers" for their freshwater supply because a large fraction of the available runoff is due to rainfall or snowmelt from high-elevation areas (Viviroli et al. 2007). A good knowledge of the spatial distribution of 
precipitation over complex terrain is required for most hydrological applications. The spatial variability of precipitation in mountainous regions is, however, not adequately captured by a generally sparse gauging network (e.g., Barry 1992; Viviroli and Weingartner 2004). There are also limitations of snow gauging under windy conditions (Gascoin et al. 2013). Moreover, weather radar data are usually not available in the subtropical Andes region. As a result of these drawbacks, the precipitation input is often the main source of uncertainty in hydrological models.

The typical approach to distribute precipitation measurements from available rain/snow gauges to the catchment scale is to include some sort of dependency between the accumulated precipitation and the terrain elevation (Daly et al. 1994; Valéry et al. 2010). However, this dependency can be highly variable in complex topography because of atmospheric processes including dynamical, thermodynamical, and microphysical effects (Roe 2005; Austin and Dirks 2006; Rotunno and Houze 2007; Lundquist et al. 2010; Houze 2012). For instance, the enhancement of precipitation due to the topography is associated with mechanical lifting of moist air on the windward side of a barrier. In a stably stratified atmosphere, blocking of the impinging airflow may occur as denser air dams against the mountain slope and becomes subgeostrophic, turning toward lower pressures. The geostrophic adjustment results in a poleward barrier jet along the slope [e.g., Parish (1982) for the Sierra barrier jet; Rutllant (1983) and Kalthoff et al. (2002) for the Andes barrier jet]. The barrier jet and its associated secondary circulation can subsequently alter the orographic precipitation gradient (OPG) across a given slope.

The Elqui basin is located along the windward side of the subtropical Andes Mountains at $30^{\circ} \mathrm{S}$ (Figs. 1a,b). At that latitude the Andes reach a mean altitude around $5000 \mathrm{~m}$ at about $140 \mathrm{~km}$ from the coast (Figs. 1c,d). The mean annual precipitation is less than $100 \mathrm{~mm}$ along the coast (La Serena) and exceeds $300 \mathrm{~mm}$ over $3000 \mathrm{~m}$ MSL (La Laguna dam). Precipitation measurements over the last 40 years reveal that $93 \%$ of the total annual precipitation occurs during the austral winter season between April and September. About 2-3 events per year contribute $60 \%$ of the total precipitation at the coast and $40 \%$ in the highlands. Therefore, water availability during the subsequent dry season highly depends on the orographic precipitation distribution of just these few storms every year (Masiokas et al. 2006; Falvey and Garreaud 2007; Favier et al. 2009; Viale and Nuñez 2011).

Similar to central Chile, interannual precipitation variability in the Elqui basin is strongly modulated by the ENSO cycle (e.g., Rutllant and Fuenzalida 1991). Intraseasonal variability of significant precipitation events has been related with the Madden-Julian oscillation (MJO; e.g., Juliá et al. 2012). Here, the common mechanism for an increase of precipitation during the warm phase of ENSO and the ENSO-like MJO phase is related to a weakened southeast Pacific subtropical anticyclone (SEPSA) off central Chile and blocking of the westerlies at high latitudes in the southeast Pacific associated with a higher frequency of frontal, midlatitude baroclinic disturbances that reach subtropical latitudes (Escobar and Aceituno 1998; Falvey and Garreaud 2007; Barrett et al. 2011; Garreaud 2013). In addition to surface frontal activity, cutoff lows have been found to account for about $40 \%$ of the mean annual precipitation at $30^{\circ} \mathrm{S}$ (Barahona 2013). Cyclonic circulation induced by the cutoff low may occasionally penetrate into the lower troposphere and dissipate through diabatic processes of friction (Rondanelli et al. 2002; Fuenzalida et al. 2005; Garreaud and Fuenzalida 2007).

Recent studies in the north-central region in Chile have tried to understand orographic precipitation using different approaches. For example, statistical downscaling was used to improve the precipitation spatial distribution, but a nonnegligible high bias was obtained (Souvignet and Heinrich 2011). Bourgin et al. (2012) generated gridded monthly precipitation data between 1975 and 2006 for north-central Chile at a 1-km grid spacing that was based on the interpolation of gauge data based on a fixed OPG. Synoptic-scale meteorological studies have stressed the strong relation between the zonal moisture flux and the orographic precipitation distribution, particularly in the case of warm storms in central Chile (Garreaud 2013; Falvey and Garreaud 2007).

To better understand the OPG for storms that produce significant precipitation, we assess the degree of blocking of the Andes on the impinging moist airflow. To this end, we calculate the Froude number $(\mathrm{Fr})$ and the position of the Andes barrier jet (ABJ) from reanalysis data. Several studies on mountainous regions have related these parameters to the precipitation distribution with altitude. For instance, Hughes et al. (2009) analyzed Fr over the coastal California range in the United States, while Barrett et al. (2011) performed the same analysis over the Andes Mountains in central Chile. Both studies show a positive correlation between OPG and Fr, especially for large positive OPGs, while in highly blocked conditions (i.e., negative OPGs), this correlation has not been evident (Neiman et al. 2010). On the other hand, altitude and strength of the barrier jet have been related to the spatial precipitation 


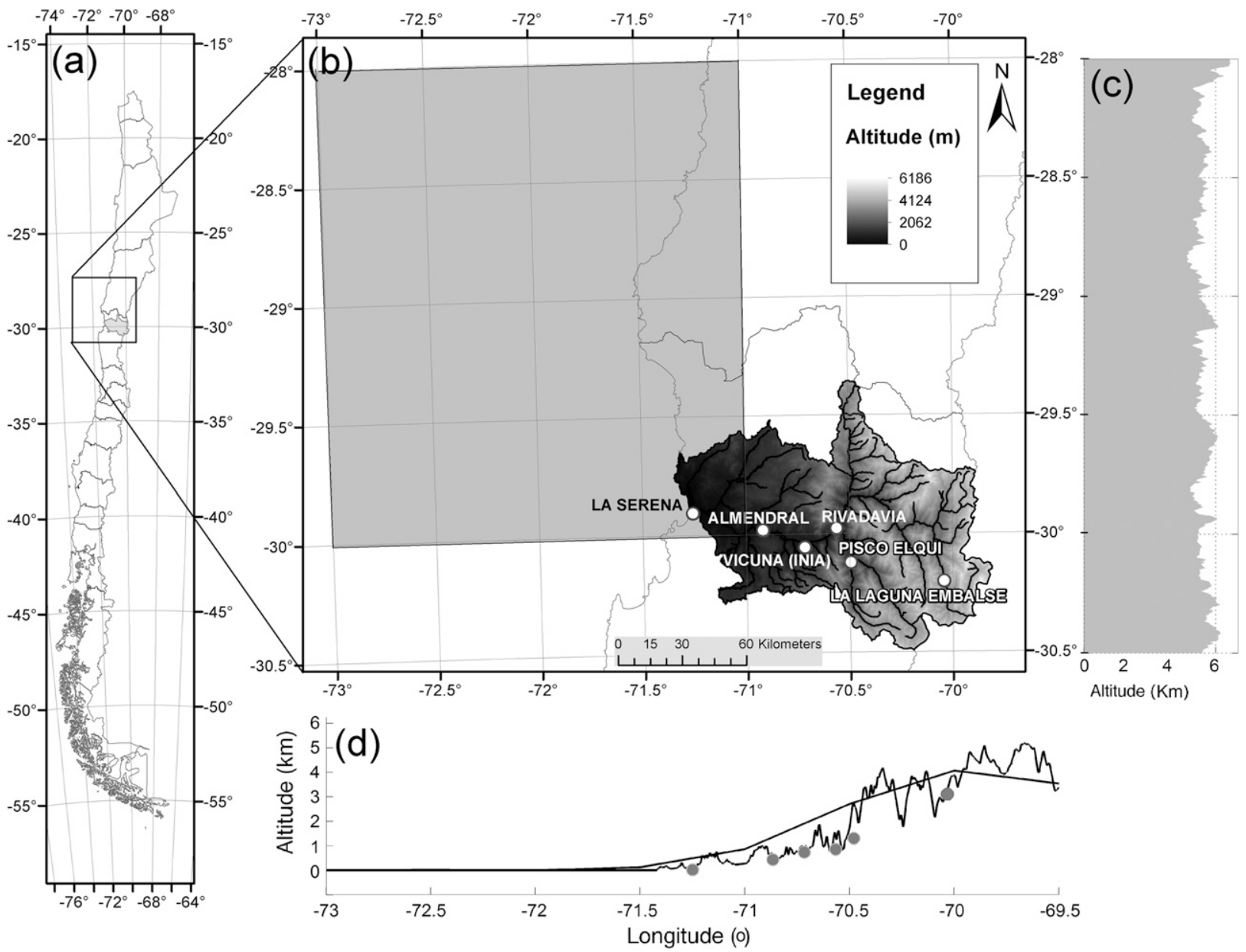

FIG. 1. (a) Location of the study area in north-central Chile. (b) The Elqui basin and selected meteorological stations. (c) Maximum altitude of the Andes within the selected latitude span. (d) Topographic west-east mean cross section between $29.5^{\circ}$ and $30.5^{\circ} \mathrm{S}$ from the Advanced Spaceborne Thermal Emission and Reflection Radiometer (ASTER) Global Digital Elevation Model (a product from Japan's Ministry of Economy, Trade and Industry and NASA) with a 30-m resolution in altitude above mean sea level. The rectangular inset in (b) is the upwind area selected to calculate the Froude numbers (gray area).

distribution in California's Sierra Nevada (Lundquist et al. 2010; Neiman et al. 2010).

In this study, we characterize the degree of orographic blocking of the impinging zonal flow and associated synoptic weather patterns for the most significant precipitation events between 1979 and 2013 along the Elqui basin in the semiarid north-central Chile $\left(30^{\circ} \mathrm{S}\right)$. Section 2 describes data sources including local observations and reanalysis of meteorological fields. The methodologies to characterize significant precipitation storms and to assess the degree of the blocking of the impinging airflow over the Andes are given in section 3. Results are presented in section 4 including meso- and synopticscale analyses that are illustrated by representative case studies of each of the two main types of storms discussed in section 3. Finally, section 5 contains a summary and discussion of the results.

\section{Datasets}

\section{a. Observed data}

Six rain gauge stations (Table 1) from the Dirección General de Aguas (DGA; Chile) were chosen to analyze the precipitation gradient over the Elqui Valley. Historical records, consisting of daily reports at 1200 UTC

TABLE 1. Location of precipitation gauge stations.

\begin{tabular}{lccc}
\hline \multicolumn{1}{c}{ Official station name } & Lat & Lon & Alt (m MSL) \\
\hline La Serena (Escuela Agricola) & $29.90^{\circ} \mathrm{S}$ & $71.25^{\circ} \mathrm{W}$ & 15 \\
Almendral & $29.98^{\circ} \mathrm{S}$ & $70.87^{\circ} \mathrm{W}$ & 430 \\
Vicuna & $30.05^{\circ} \mathrm{S}$ & $70.72^{\circ} \mathrm{W}$ & 730 \\
Rivadavia & $29.97^{\circ} \mathrm{S}$ & $70.57^{\circ} \mathrm{W}$ & 850 \\
Pisco Elqui & $30.12^{\circ} \mathrm{S}$ & $70.48^{\circ} \mathrm{W}$ & 1300 \\
La Laguna (Embalse) & $30.20^{\circ} \mathrm{S}$ & $70.03^{\circ} \mathrm{W}$ & 3100 \\
\hline
\end{tabular}


(0800 LST), were retrieved over the period 1979-2013. The historical metadata document indicates that a Hellmann rain gauge was used to measure precipitation from most of the stations (except the uppermost station, La Laguna).

The uppermost precipitation gauge is located in a flat area at $3100 \mathrm{~m}$ MSL near the outlet of La Laguna Reservoir. Meteorological observations at this site are considered representative of the surroundings by the local water agency. At La Laguna, winter precipitation falls as snow. Fresh snow accumulation is measured at 0800 LST (1200 UTC) in the camp's yard (see Fig. S1 in the supplemental material) by averaging 3-4 stick measurements around it. In addition, the meteorological station has a standard bucket rain gauge without a wind shield that is operated without the external funnel to avoid getting stuck by the snow (see Fig. S2 in the supplemental material). At this site there is always an operator from the organization in charge of the dam who maintains the site at all times. This guarantees reliable data at La Laguna station. Operators empirically estimate around a $50 \%$ loss in snow catch due to the lack of a wind shield. Therefore, approximately twice the amount collected in the rain gauge should be compared with the snow depth (centimeters), a value that should closely match the snow water equivalent in millimeters, assuming fresh snow with $10 \%$ of the water density. Since these two assumptions can vary within individual storms, the National Water Agency only keeps the raw rain gauge measurement in their digital records, despite the fact that daily mean snow depths are also recorded in their monthly forms. For the purposes of this study, uncertainty in the absolute value of La Laguna precipitation only changes the absolute value of OPGs, without altering the conclusions that are drawn from the comparison between high and low OPGs during the selected storms. The impacts of this issue will be revisited in section 5 .

\section{b. Climate Forecast System Reanalysis}

The Climate Forecast System Reanalysis (CFSR; Saha et al. 2010) is used to assess the synoptic meteorological conditions during selected storms. CFSR data are available from 1979 to present with a regular $0.5^{\circ} \times$ $0.5^{\circ}$ horizontal spatial grid and a mean vertical resolution between 350 and $900 \mathrm{~m}$ below $300 \mathrm{hPa}$. The CFSR is also used to calculate Fr and the main features of the ABJ. To assess the ability of the CFSR to represent a barrier jet, 915-MHz radar wind profiler data from two locations in California's Sierra Nevada [currently operated by NOAA's Hydrometeorological Testbed (HMT; http://hmt.noaa.gov/)] were compared with CFSR. Wind profiles for the cold season during precipitation events
TABLE 2. Coordinates of wind profiler stations at the Sierra Nevada.

\begin{tabular}{lcccc}
\hline \hline \multicolumn{1}{c}{ Name } & Code & Lat & Lon & Alt (m MSL) \\
\hline Chico & CCO & $39.69^{\circ} \mathrm{S}$ & $121.91^{\circ} \mathrm{W}$ & 41 \\
Chowchilla & $\mathrm{CCL}$ & $37.11^{\circ} \mathrm{S}$ & $120.24^{\circ} \mathrm{W}$ & 76 \\
\hline
\end{tabular}

between the years 2000 and 2010 were retrieved at Chico (CCO) and Chowchilla (CCL), located on the north and south end of California's Sierra Nevada, respectively (Table 2). To identify the Sierra barrier jet during precipitation events, the criteria from Neiman et al. (2010) were used. The Sierra barrier jet was found in $61 \%$ of all the events recorded at CCO. Although the maximum speed and its altitude appear reasonably well represented in the CFSR, both variables are underestimated for speeds exceeding $25 \mathrm{~m} \mathrm{~s}^{-1}$ and heights above $1500 \mathrm{~m}$ MSL. These biases are commonly reported in atmospheric models when the resolution is coarse (Mass et al. 2002). Similar results were found at CCL for the same period of years where $68 \%$ of the wind profile observations during storm events featured a Sierra barrier jet.

\section{Methodology}

\section{a. Definition and selection of significant storm events}

Since most of the total annual precipitation is concentrated in a few storms, a "significant precipitation event" is defined as one lasting one or more consecutive days with total accumulation exceeding about $20 \%$ of the mean total annual precipitation. According to this criterion, at La Serena (coastal station) and at La Laguna (inland highest station) a significant event has to exceed 20 and $30 \mathrm{~mm}$ per storm, given the mean annual accumulations of 99 and $158 \mathrm{~mm}$, respectively.

From the selected significant precipitation events, the associated OPGs are estimated from observed precipitation data along the principal (west-east) axis of the valley, as a linear least squares regression between the total precipitation in each event against the station's altitude.

\section{b. Froude number calculation}

The Froude number is calculated to quantify the degree of blocking of the impinging airflow by the mountain range. The square of Fr represents the ratio between the kinetic energy of the incident flow and the potential energy that is necessary to pass over the mountain (e.g., Wallace and Hobbs 2006; Hughes et al. 2009):

$$
\mathrm{Fr}=\frac{U}{N H},
$$


where $U$ is the wind speed perpendicular to the topographic barrier, $N$ is the Brunt-Väisälä frequency (representing static stability), and $H$ is the characteristic mountain height.

Following Durran and Klemp (1982), the nonsaturated Brunt-Väisälä frequency $N_{d}$, when the relative humidity $(\mathrm{RH})$ values are under $90 \%$, is calculated as

$$
N_{d}^{2}=\frac{g}{\theta_{v}} \frac{d \theta_{v}}{d z}
$$

where $g$ is gravity and $\theta_{v}$ is the virtual potential temperature. For RH above $90 \%$, moist adiabatic conditions should be introduced in a saturated Brunt-Väisälä frequency, resulting in

$$
N_{m}^{2}=\frac{g}{T}\left(\frac{d T}{d z}+\Gamma_{m}\right)\left(1+\frac{L_{v} q}{R_{d} T}\right)-\frac{g}{1+q} \frac{d q}{d z}
$$

where $T$ is the air temperature, $\Gamma_{m}$ is the moist adiabatic lapse rate, $q$ is the specific humidity, $L_{v}$ is the latent heat for evaporation, and $R_{d}$ is the specific gas constant for dry air.

Given the meridional orientation of the Andes, the zonal wind component represents the flow perpendicular to the topography. Since many significant precipitation events are characterized by west-northwest winds, the upwind area is taken slightly to the northwest of the study area. Thus, Fr is calculated considering both dry and saturated free atmospheric conditions [from Eqs. (1) to (3)] over a horizontal area (grid space of $\left.0.5^{\circ} \times 0.5^{\circ}\right)$ located upwind of the Andes range $\left(28^{\circ}-\right.$ $30^{\circ} \mathrm{S}, 73^{\circ}-71^{\circ} \mathrm{W}$; see the square inset in Fig. $1 \mathrm{~b}$ ) in the 700-500-hPa layer (five levels in the CFSR). The Fr in this layer (between 700 and $500 \mathrm{hPa}$ ) is the best at discriminating between the two types of storms discussed here. The characteristic height of the Andes range within this domain was taken as $4000 \mathrm{~m}$.

\section{c. Andes barrier jet criteria}

In this study, some modifications are made to the criteria in Neiman et al. (2010), which define the Sierra barrier jet. The modifications to define the ABJ are basically due to a steeper slope, a shorter distance to the coast, and a lack of in situ data as compared with the Sierra Nevada. Thus, to define the presence of an ABJ, the maximum wind speed along the Andes Cordillera has to be at least $12 \mathrm{~m} \mathrm{~s}^{-1}$ at a pressure level between 850 (around $1600 \mathrm{~m} \mathrm{MSL}$ ) and $600 \mathrm{hPa}$ (around $4300 \mathrm{~m}$ MSL). In addition, the wind shear was only required to be negative above the maximum wind and up to a 5000-m altitude (near the top of the Andes at $30^{\circ} \mathrm{S}$ ). A

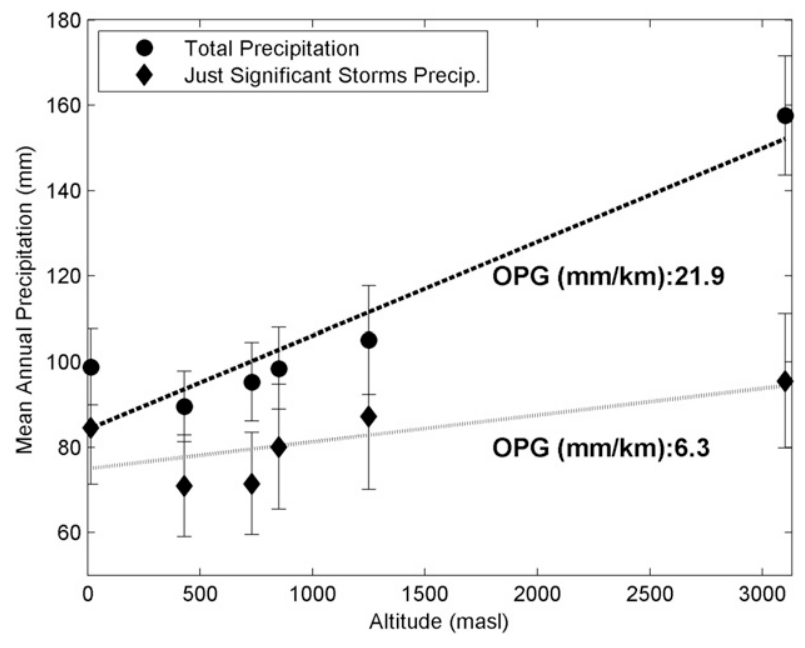

FIG. 2. Mean annual precipitation for the six stations along the main axis of the Elqui Valley vs their corresponding altitudes. Circles show total mean annual precipitation and diamonds correspond to annual precipitation accumulated only during significant events. The standard error bars and linear regression for each dataset is indicated, yielding the corresponding mean OPG.

time constraint is also imposed to define an ABJ representative of any particular storm: the ABJ should be present for at least half of the precipitation event duration.

\section{Results}

\section{a. Variability of the orographic precipitation gradient}

Between 1979 and 2013, 77 significant precipitation events at either the coastal site (La Serena) or in the highlands (La Laguna dam) were found. The mean precipitation distribution of these 77 storms against the station altitude is depicted in Fig. 2. The list of the selected events with their percent contribution to the mean annual precipitation at their respective station appears in Table 3.

Most of the annual rainfall $(85.6 \%)$ at the coastal site is from significant events. However, in the highlands significant events only account for about $60.6 \%$ of the annual precipitation, indicating the importance of more frequent and relatively less intense precipitation events. The smaller contribution to the total precipitation by the significant storms in the upper part of the Andes could be interpreted as a result of the orographic blocking, producing less intense precipitation events that nonetheless significantly modify the annual OPG. On the other hand, significant coastal storms should be less affected by orographic blocking, so that precipitation should be controlled by other mechanisms such as a higher amount of moisture in 
TABLE 3. Summary of all significant precipitation events. The percentages are the fractional contributions to the mean annual precipitation for each station. Mean annual precipitation is calculated between 1979 and 2013. In boldface font are the extreme coast-only and highland-only events.

\begin{tabular}{|c|c|c|c|c|c|c|c|c|}
\hline No. & \multirow[b]{2}{*}{ Initial date } & \multirow[b]{2}{*}{$\begin{array}{l}\text { Final date } \\
\text { tion }(\mathrm{mm})\end{array}$} & \multicolumn{6}{|c|}{ Station names } \\
\hline Mean annual precipitation $(\mathrm{mm})$ & & & $\begin{array}{c}\text { La Serena } \\
98.79\end{array}$ & $\begin{array}{l}\text { Almendral } \\
89.55\end{array}$ & $\begin{array}{c}\text { Vicuna } \\
95.31\end{array}$ & $\begin{array}{c}\text { Rivadavia } \\
98.44\end{array}$ & $\begin{array}{c}\text { Pisco Elqui } \\
105.08\end{array}$ & $\begin{array}{c}\text { La Laguna } \\
157.61\end{array}$ \\
\hline 1 & 10 Apr 1980 & 11 Apr 1980 & $37 \%$ & $18 \%$ & $47 \%$ & $63 \%$ & $93 \%$ & $62 \%$ \\
\hline 2 & 14 May 1980 & 18 May 1980 & $\mathbf{0} \%$ & $\mathbf{0} \%$ & $\mathbf{0} \%$ & $\mathbf{0} \%$ & $\mathbf{0} \%$ & $40 \%$ \\
\hline 3 & 23 Jun 1980 & 24 Jun 1980 & $20 \%$ & $20 \%$ & $12 \%$ & $13 \%$ & $0 \%$ & $11 \%$ \\
\hline 4 & 24 Jul 1980 & 25 Jul 1980 & $58 \%$ & $66 \%$ & $66 \%$ & $62 \%$ & $14 \%$ & $13 \%$ \\
\hline 5 & 11 May 1981 & 12 May 1981 & $59 \%$ & $36 \%$ & $24 \%$ & $13 \%$ & $10 \%$ & $\mathbf{0} \%$ \\
\hline 6 & 15 Jul 1981 & 15 Jul 1981 & $22 \%$ & $11 \%$ & $13 \%$ & $7 \%$ & $5 \%$ & $2 \%$ \\
\hline 7 & 5 Aug 1981 & 6 Aug 1981 & $7 \%$ & $5 \%$ & $10 \%$ & $15 \%$ & $16 \%$ & $23 \%$ \\
\hline 8 & 8 May 1982 & 8 May 1982 & $22 \%$ & $9 \%$ & $4 \%$ & $16 \%$ & $19 \%$ & $14 \%$ \\
\hline 9 & 15 Jul 1982 & 17 Jul 1982 & $14 \%$ & $21 \%$ & $35 \%$ & $62 \%$ & $126 \%$ & $108 \%$ \\
\hline 10 & 12 Aug 1982 & 13 Aug 1982 & $32 \%$ & $42 \%$ & $23 \%$ & $11 \%$ & $\mathbf{5} \%$ & 0\% \\
\hline 11 & $6 \mathrm{Jul} 1983$ & 8 Jul 1983 & $181 \%$ & $89 \%$ & $83 \%$ & $113 \%$ & $99 \%$ & $33 \%$ \\
\hline 12 & 28 Aug 1983 & 28 Aug 1983 & $22 \%$ & $24 \%$ & $24 \%$ & $22 \%$ & $14 \%$ & $5 \%$ \\
\hline 13 & 1 Jul 1984 & 5 Jul 1984 & $144 \%$ & $189 \%$ & $151 \%$ & $233 \%$ & $258 \%$ & $160 \%$ \\
\hline 14 & 8 Jul 1984 & $10 \mathrm{Jul} 1984$ & $68 \%$ & $69 \%$ & $92 \%$ & $91 \%$ & $83 \%$ & $19 \%$ \\
\hline 15 & 28 Jul 1985 & 29 Jul 1985 & $28 \%$ & $40 \%$ & $40 \%$ & $33 \%$ & $32 \%$ & $3 \%$ \\
\hline 16 & 27 May 1986 & 28 May 1986 & $28 \%$ & $15 \%$ & $13 \%$ & $7 \%$ & $8 \%$ & $10 \%$ \\
\hline 17 & 12 Aug 1986 & 14 Aug 1986 & $19 \%$ & $35 \%$ & $27 \%$ & $25 \%$ & $25 \%$ & $21 \%$ \\
\hline 18 & 5 May 1987 & 5 May 1987 & $24 \%$ & $9 \%$ & $9 \%$ & $5 \%$ & $6 \%$ & $2 \%$ \\
\hline 19 & 8 Jul 1987 & 11 Jul 1987 & $7 \%$ & $21 \%$ & $16 \%$ & $26 \%$ & $60 \%$ & $41 \%$ \\
\hline 20 & $15 \mathrm{Jul} 1987$ & 16 Jul 1987 & $43 \%$ & $45 \%$ & $24 \%$ & $22 \%$ & $33 \%$ & $8 \%$ \\
\hline 21 & 21 Jul 1987 & 25 Jul 1987 & $170 \%$ & $135 \%$ & $118 \%$ & $123 \%$ & $65 \%$ & $47 \%$ \\
\hline 22 & 10 Aug 1987 & 14 Aug 1987 & $11 \%$ & $8 \%$ & $10 \%$ & $22 \%$ & $54 \%$ & $120 \%$ \\
\hline 23 & 19 Aug 1989 & 20 Aug 1989 & - & - & - & $29 \%$ & - & $29 \%$ \\
\hline 24 & 30 Aug 1990 & 5 Sep 1990 & $3 \%$ & 0\% & $1 \%$ & $2 \%$ & $1 \%$ & $21 \%$ \\
\hline 25 & 26 May 1991 & 27 Мay 1991 & 0\% & 0\% & 0\% & $\mathbf{0} \%$ & $2 \%$ & $26 \%$ \\
\hline 26 & 16 Jun 1991 & 21 Jun 1991 & $89 \%$ & $104 \%$ & $132 \%$ & $133 \%$ & $114 \%$ & $46 \%$ \\
\hline 27 & 16 Jul 1991 & 19 Jul 1991 & $28 \%$ & $40 \%$ & $39 \%$ & $33 \%$ & $25 \%$ & $16 \%$ \\
\hline 28 & 26 Mar 1992 & 26 Mar 1992 & $28 \%$ & $25 \%$ & $28 \%$ & $30 \%$ & $26 \%$ & $9 \%$ \\
\hline 29 & 5 Jun 1992 & 8 Jun 1992 & $167 \%$ & $78 \%$ & $80 \%$ & $92 \%$ & $62 \%$ & $21 \%$ \\
\hline 30 & 24 Jun 1992 & 25 Jun 1992 & $26 \%$ & $15 \%$ & $12 \%$ & $6 \%$ & $2 \%$ & 0\% \\
\hline 31 & 6 May 1993 & 7 May 1993 & $33 \%$ & $4 \%$ & $1 \%$ & $3 \%$ & $10 \%$ & $16 \%$ \\
\hline 32 & 29 Jun 1994 & 29 Jun 1994 & $21 \%$ & $8 \%$ & $12 \%$ & $7 \%$ & $12 \%$ & $5 \%$ \\
\hline 33 & 19 Jul 1994 & 20 Jul 1994 & $2 \%$ & $8 \%$ & $20 \%$ & $47 \%$ & $37 \%$ & $37 \%$ \\
\hline 34 & 3 Jul 1996 & 7 Jul 1996 & $28 \%$ & $8 \%$ & $18 \%$ & $20 \%$ & $15 \%$ & $4 \%$ \\
\hline 35 & 3 Jun 1997 & 4 Jun 1997 & $18 \%$ & $19 \%$ & $31 \%$ & $36 \%$ & $53 \%$ & $22 \%$ \\
\hline 36 & 10 Jun 1997 & 12 Jun 1997 & $66 \%$ & $86 \%$ & $76 \%$ & $91 \%$ & $88 \%$ & - \\
\hline 37 & 18 Jun 1997 & 19 Jun 1997 & $13 \%$ & $33 \%$ & $6 \%$ & $14 \%$ & $56 \%$ & $40 \%$ \\
\hline 38 & 16 Aug 1997 & 18 Aug 1997 & $71 \%$ & $136 \%$ & $118 \%$ & $162 \%$ & $154 \%$ & $101 \%$ \\
\hline 39 & 4 Sep 1999 & 7 Sep 1999 & $7 \%$ & $7 \%$ & $18 \%$ & $39 \%$ & $20 \%$ & $29 \%$ \\
\hline 40 & 23 Jun 2000 & 24 Jun 2000 & $21 \%$ & $49 \%$ & $53 \%$ & $48 \%$ & $32 \%$ & $13 \%$ \\
\hline 41 & 27 Jun 2000 & $1 \mathrm{Jul} 2000$ & $11 \%$ & $7 \%$ & $11 \%$ & $26 \%$ & $31 \%$ & $27 \%$ \\
\hline 42 & 7 Jul 2000 & 9 Jul 2000 & $\mathbf{0} \%$ & $5 \%$ & $14 \%$ & $4 \%$ & $1 \%$ & $22 \%$ \\
\hline 43 & 7 Sep 2000 & 9 Sep 2000 & $24 \%$ & $23 \%$ & $17 \%$ & $20 \%$ & $8 \%$ & $3 \%$ \\
\hline 44 & 17 Jul 2001 & 19 Jul 2001 & $67 \%$ & $43 \%$ & $25 \%$ & $21 \%$ & $40 \%$ & $19 \%$ \\
\hline 45 & 25 Aug 2001 & 27 Aug 2001 & $43 \%$ & $29 \%$ & $42 \%$ & $34 \%$ & $27 \%$ & $26 \%$ \\
\hline 46 & 29 Sep 2001 & 29 Sep 2001 & $20 \%$ & $11 \%$ & $8 \%$ & 0\% & 0\% & 0\% \\
\hline 47 & 13 May 2002 & 14 May 2002 & $15 \%$ & $25 \%$ & $13 \%$ & $31 \%$ & $26 \%$ & $27 \%$ \\
\hline 48 & 25 May 2002 & 26 May 2002 & $49 \%$ & $41 \%$ & $54 \%$ & $48 \%$ & $42 \%$ & $25 \%$ \\
\hline 49 & 1 Jul 2002 & 2 Jul 2002 & $\mathbf{0} \%$ & 0\% & 0\% & $5 \%$ & - & $30 \%$ \\
\hline 50 & 20 Jul 2002 & 23 Jul 2002 & $77 \%$ & $64 \%$ & $104 \%$ & $78 \%$ & $92 \%$ & $37 \%$ \\
\hline 51 & 25 Aug 2002 & 27 Aug 2002 & $40 \%$ & $40 \%$ & $30 \%$ & $21 \%$ & $17 \%$ & $3 \%$ \\
\hline 52 & 20 May 2003 & 21 May 2003 & $68 \%$ & $90 \%$ & $62 \%$ & $30 \%$ & $58 \%$ & $24 \%$ \\
\hline 53 & $3 \mathrm{Jul} 2003$ & 7 Jul 2003 & $19 \%$ & $12 \%$ & $8 \%$ & $14 \%$ & $20 \%$ & $36 \%$ \\
\hline 54 & $20 \mathrm{Jul} 2004$ & $21 \mathrm{Jul} 2004$ & $45 \%$ & $46 \%$ & $36 \%$ & $42 \%$ & $13 \%$ & $7 \%$ \\
\hline
\end{tabular}


TABLE 3. (Continued)

\begin{tabular}{|c|c|c|c|c|c|c|c|c|}
\hline \multirow[b]{2}{*}{ No. } & Initial date & \multirow[b]{2}{*}{$\begin{array}{l}\text { Final date } \\
\text { tion }(\mathrm{mm})\end{array}$} & \multicolumn{6}{|c|}{ Station names } \\
\hline & Mean annual precipitation (mm) & & $\begin{array}{c}\text { La Serena } \\
98.79\end{array}$ & $\begin{array}{c}\text { Almendral } \\
\quad 89.55\end{array}$ & $\begin{array}{c}\text { Vicuna } \\
95.31\end{array}$ & $\begin{array}{c}\text { Rivadavia } \\
98.44\end{array}$ & $\begin{array}{c}\text { Pisco Elqui } \\
105.08\end{array}$ & $\begin{array}{c}\text { La Laguna } \\
157.61\end{array}$ \\
\hline 55 & $26 \mathrm{Jul} 2004$ & $27 \mathrm{Jul} 2004$ & $28 \%$ & $36 \%$ & $34 \%$ & $14 \%$ & $14 \%$ & $23 \%$ \\
\hline 56 & 2 Aug 2004 & 4 Aug 2004 & $21 \%$ & $5 \%$ & $11 \%$ & $4 \%$ & $\mathbf{0} \%$ & $\mathbf{0} \%$ \\
\hline 57 & 24 Apr 2005 & 27 Apr 2005 & $\mathbf{0} \%$ & $\mathbf{0} \%$ & $4 \%$ & $8 \%$ & $7 \%$ & $23 \%$ \\
\hline 58 & 10 Jun 2005 & 18 Jun 2005 & $1 \%$ & $\mathbf{0} \%$ & $\mathbf{0} \%$ & $\mathbf{0} \%$ & $\mathbf{0} \%$ & $49 \%$ \\
\hline 59 & 27 Aug 2005 & 28 Aug 2005 & $\mathbf{0} \%$ & $\mathbf{0} \%$ & $4 \%$ & $15 \%$ & $25 \%$ & $23 \%$ \\
\hline 60 & 6 Jun 2006 & 8 Jun 2006 & $21 \%$ & $7 \%$ & $4 \%$ & $4 \%$ & $3 \%$ & $6 \%$ \\
\hline 61 & 10 Jul 2006 & 12 Jul 2006 & $\mathbf{0} \%$ & 0\% & 0\% & $\mathbf{0} \%$ & $8 \%$ & $24 \%$ \\
\hline 62 & 25 Jul 2006 & 26 Jul 2006 & $30 \%$ & $38 \%$ & $36 \%$ & $18 \%$ & $7 \%$ & 0\% \\
\hline 63 & 12 Jun 2007 & 14 Jun 2007 & $12 \%$ & $25 \%$ & $10 \%$ & $7 \%$ & $22 \%$ & $47 \%$ \\
\hline 64 & 5 Jul 2007 & 7 Jul 2007 & 0\% & $6 \%$ & 0\% & $7 \%$ & $7 \%$ & $56 \%$ \\
\hline 65 & 26 May 2008 & 27 May 2008 & $10 \%$ & $12 \%$ & $21 \%$ & $14 \%$ & $12 \%$ & $20 \%$ \\
\hline 66 & 18 Jun 2008 & 18 Jun 2008 & $32 \%$ & $50 \%$ & $20 \%$ & $48 \%$ & $49 \%$ & $16 \%$ \\
\hline 67 & $20 \mathrm{Jul} 2008$ & 21 Jul 2008 & $20 \%$ & $18 \%$ & $9 \%$ & $15 \%$ & $22 \%$ & - \\
\hline 68 & 16 Aug 2008 & 17 Aug 2008 & $52 \%$ & $58 \%$ & $76 \%$ & $45 \%$ & $71 \%$ & $24 \%$ \\
\hline 69 & 27 Jun 2009 & 28 Jun 2009 & $22 \%$ & $42 \%$ & $25 \%$ & $33 \%$ & $16 \%$ & $6 \%$ \\
\hline 70 & 15 Aug 2009 & 15 Aug 2009 & $30 \%$ & $25 \%$ & $24 \%$ & $22 \%$ & $71 \%$ & $4 \%$ \\
\hline 71 & 17 Jun 2010 & 18 Jun 2010 & $23 \%$ & $20 \%$ & $22 \%$ & $16 \%$ & $14 \%$ & $5 \%$ \\
\hline 72 & 5 Jun 2011 & 6 Jun 2011 & $106 \%$ & $46 \%$ & $37 \%$ & $34 \%$ & $28 \%$ & $15 \%$ \\
\hline 73 & 18 Jun 2011 & 20 Jun 2011 & $54 \%$ & $39 \%$ & $40 \%$ & $26 \%$ & $49 \%$ & $8 \%$ \\
\hline 74 & 15 Jul 2011 & 15 Jul 2011 & $22 \%$ & $28 \%$ & $20 \%$ & $17 \%$ & $14 \%$ & $4 \%$ \\
\hline 75 & 25 May 2012 & 26 May 2012 & $\mathbf{0} \%$ & 0\% & 0\% & $\mathbf{0} \%$ & $\mathbf{0} \%$ & $36 \%$ \\
\hline 76 & 15 Aug 2012 & 16 Aug 2012 & $31 \%$ & $6 \%$ & $2 \%$ & $7 \%$ & $0 \%$ & $12 \%$ \\
\hline 77 & 17 May 2013 & 18 May 2013 & $21 \%$ & $38 \%$ & $18 \%$ & $20 \%$ & $20 \%$ & $15 \%$ \\
\hline
\end{tabular}

the prestorm environment together with frontal or cyclonic convergence.

The OPG can widely vary within significant storms, as is highlighted in Fig. 3. The OPG distribution of the 77 storms is grouped into three categories: OPG $>$ $5 \mathrm{~mm} \mathrm{~km}^{-1}$ (29 events), $-5<$ OPG $<5 \mathrm{~mm} \mathrm{~km}^{-1}$ (25 events), and $\mathrm{OPG}<-5 \mathrm{~mm} \mathrm{~km}^{-1}$ (23 events).

\section{b. Mesoscale analysis: $O P G$ and upstream blocking}

This section describes how the 77 precipitation events relate to the Fr, the ABJ height, and the OPG. There are 17 significant precipitation events with $\mathrm{Fr}$ above 0.23 that represent weak blocking, and 16 significant precipitation events with Fr below 0.15 that represent strong blocking.

A zonal cross section of the average meridional wind for all 77 significant events reveals a distinct ABJ (Fig. 4), though an ABJ was found only in 60 of the 77 events. The relationship between the height of the ABJ and the OPG was also examined using only the cases where an ABJ was identified. Consistent with Lundquist et al. (2010) and Neiman et al. (2010), an inverse relationship between $\mathrm{ABJ}$ height and mean OPG was found. Figure 5 depicts the along-valley precipitation for 14 weak-blocking storms and 12 strong-blocking storms that have a defined ABJ. The weak-blocking storms have an Fr above 0.23 , a mean OPG of $8.09 \mathrm{~mm} \mathrm{~km}^{-1}$, and a mean ABJ height of $3120 \mathrm{~m}$. The strong-blocking storms have an Fr below 0.15 , a mean OPG of $-1.21 \mathrm{~mm} \mathrm{~km}^{-1}$, and a mean ABJ height of $3240 \mathrm{~m}$.

\section{c. Synoptic-scale analysis}

Synoptic weather patterns over the southeast Pacific are examined using the mean value of $500-\mathrm{hPa}$ geopotential height and anomalies from the 1979-2013 average, vertical velocity and horizontal wind at $500 \mathrm{hPa}$, and potential vorticity (PV) on the $315-\mathrm{K}$ isentropic surface. Composites are constructed for weak and strong topographic blocking as defined in Fig. 5.

The 500-hPa trough and the associated trailing ridge are more pronounced for weak-blocking significant events (larger Fr) in Fig. 6a (left). The corresponding anomaly patterns in Fig. 6b suggest a high-latitude blocking anticyclone driving storms toward the subtropics (Fig. 6b, left) and a condition compatible with a cutoff low for the blocked events (Fig. 6b, right).

Horizontal wind vectors and vertical velocities at $30^{\circ} \mathrm{S}$ in Fig. $6 \mathrm{c}$ depict stronger zonal wind components and widespread upward motion (minimum vertical velocity around $-1.2 \mathrm{~Pa} \mathrm{~s}^{-1}$ ) along the windward slope and a strong descent (maximum vertical velocity up to 
(a)

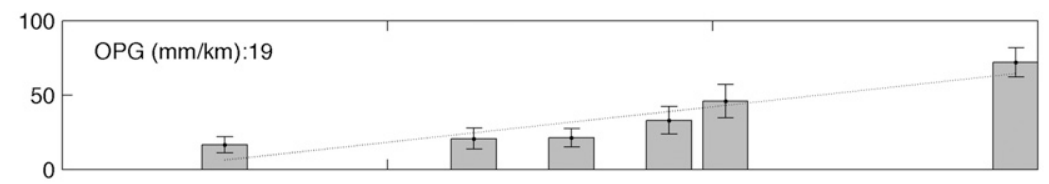

(b)

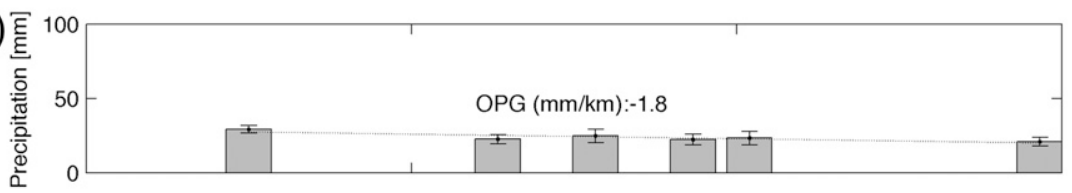

(c)

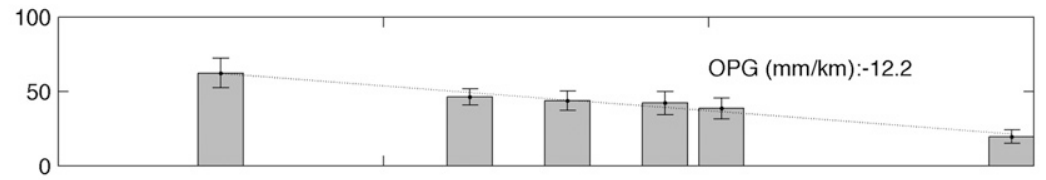

(d)

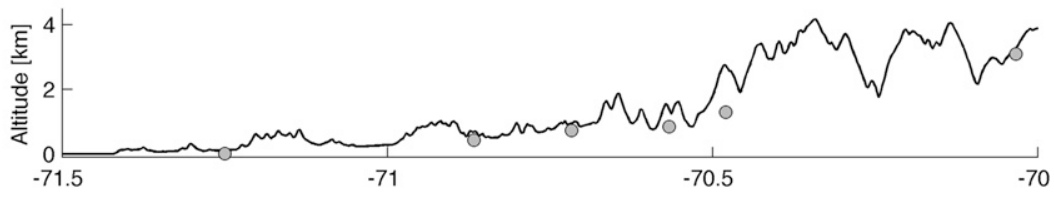

FIG. 3. Mean and std dev of precipitation for significant precipitation events for the following OPG categories: (a) OPG $>5 \mathrm{~mm} \mathrm{~km}^{-1}$ (29 events), (b) $-5<\mathrm{OPG}<5 \mathrm{~mm} \mathrm{~km}^{-1}$ ( 25 events), and (c) OPG $<-5 \mathrm{~mm} \mathrm{~km}^{-1}$ (23 events). (d) A topographic cross section along the Elqui Valley axis indicating the altitude of the stations with circles.

1.6 $\mathrm{Pa} \mathrm{s}^{-1}$ ) in the leeward slope for weak-blocked conditions (Fig. 6c, left). Weaker and spatially confined vertical velocities (ranges from -0.4 to $0.8 \mathrm{~Pa} \mathrm{~s}^{-1}$ ) appear under strong-blocked conditions at $500 \mathrm{hPa}$ (Fig. 6c, right).

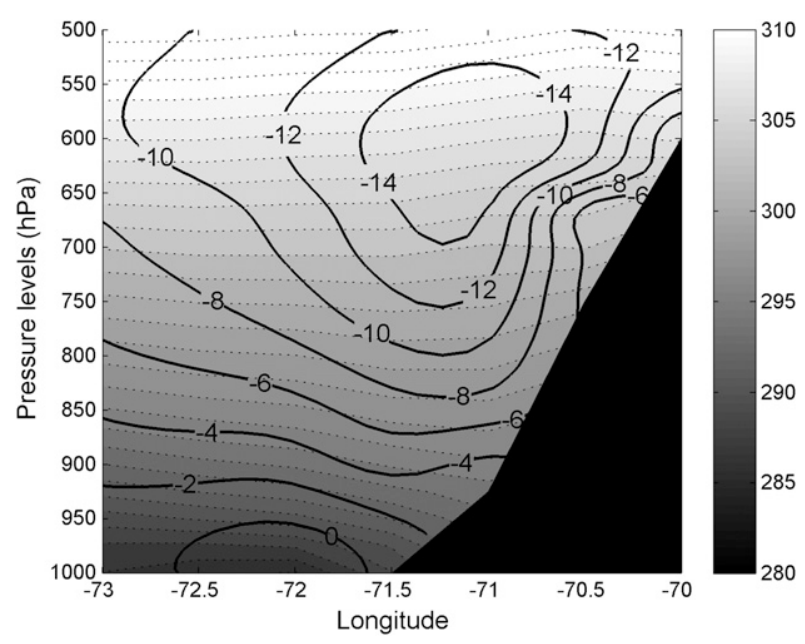

FIG. 4. Mean vertical meridional wind distribution along the windward slope of the Andes at $30^{\circ} \mathrm{S}$ for strong precipitation events (77 events). Solid contours represent meridional wind speed $\left(\mathrm{m} \mathrm{s}^{-1}\right)$. Dotted contours depict potential temperature (K). The masked topography corresponds to the CFSR representation along $30^{\circ} \mathrm{S}$.
During weak-blocking significant precipitation events, PV anomalies on the 315-K isentropic surface (Fig. 6d, left) and around the study area are cyclonic and centered close to $40^{\circ} \mathrm{S}$ with a northwest-southeast axis. This resembles a Rossby wave response due to a high-latitude

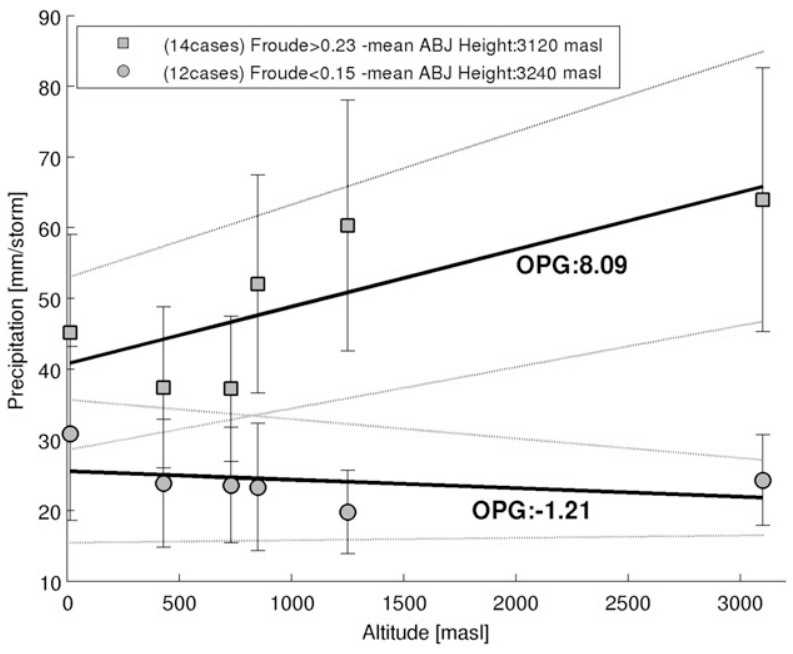

FIG. 5. OPG comparison for 14 events with $\mathrm{Fr}>0.23$ and 12 events with $\mathrm{Fr}<0.15$, calculated between 700 and $500 \mathrm{hPa}$. Dotted lines represent linear fit to the standard error $[(\operatorname{std} \mathrm{dev}) / \sqrt{n}]$ with $n$ the number of events to calculate the mean OPG, which are depicted as vertical bars around circles and squares. 
$\mathrm{Fr}>0.23$

a)

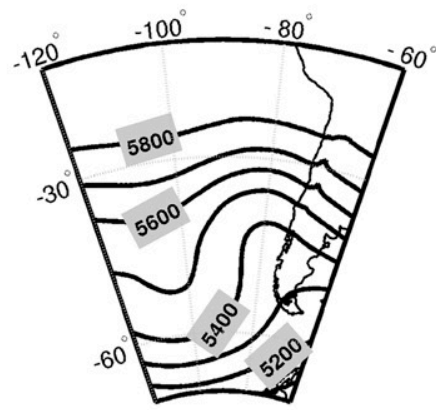

b)

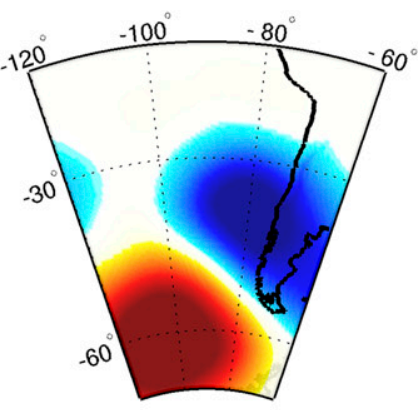

c)

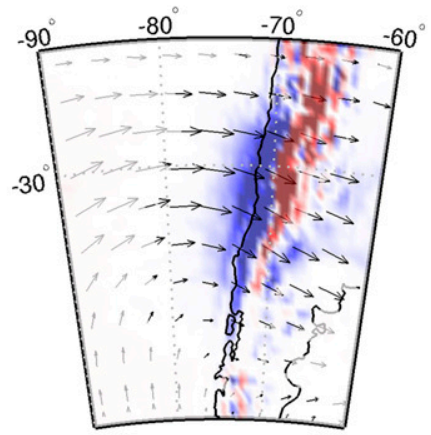

d)

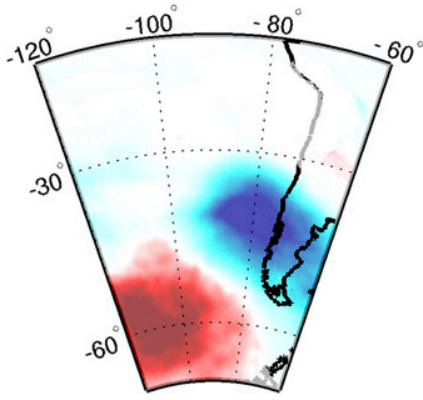

$\operatorname{Fr}<0.15$
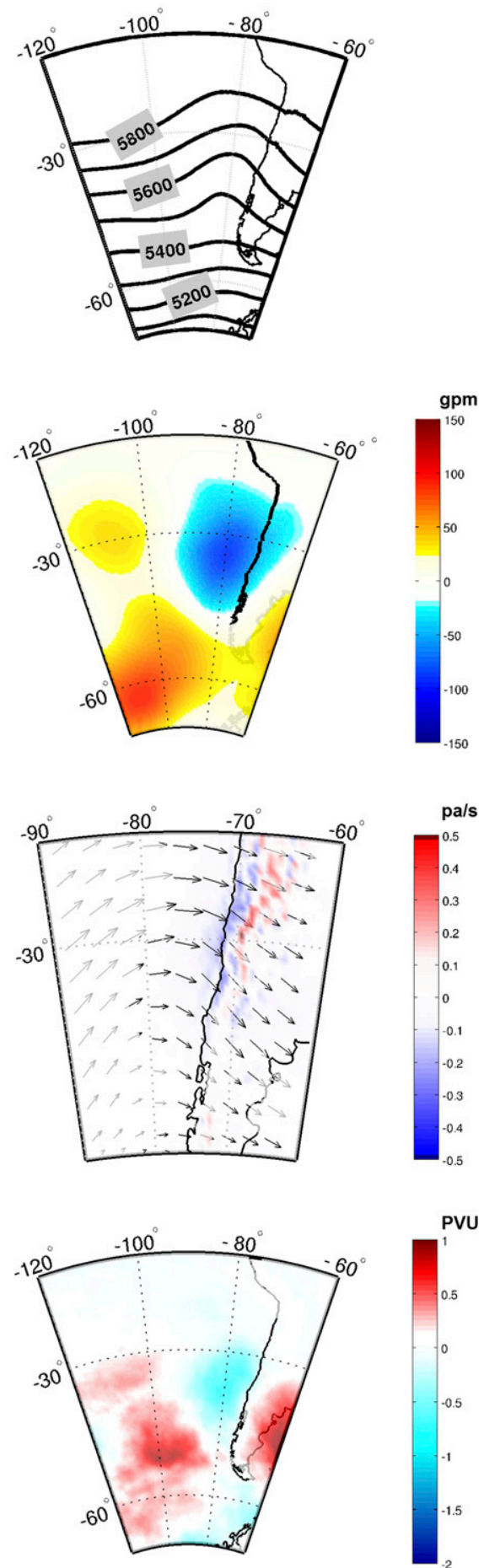

FIG. 6. (left) The 14 events with Fr $>0.23$ and (right) 12 events with $\mathrm{Fr}<0.15$ calculated between 700 and $500 \mathrm{hPa}$, shown as (a) $500-\mathrm{hPa}$ geopotential height composites (km; contours), (b) their corresponding anomaly [gpm; shaded in red (blue) for anticyclonic (cyclonic) anomalies], (c) 500-hPa composites of horizontal wind (arrows) and vertical motion ( $\mathrm{Pa} \mathrm{s}^{-1}$; color shading), and (d) PV anomaly composites in potential vorticity units (PVU; where $1 \mathrm{PVU}=10^{-6} \mathrm{~m}^{2} \mathrm{~kg} \mathrm{~s}^{-1}$ ) at the $315-\mathrm{K}$ isentropic level. 
block in the westerlies [e.g., Fig. 7 in Renwick and Revell (1999)]. For the strong-blocking condition, an isolated cyclonic PV anomaly is consistent with a cutoff low.

\section{d. Representative cases}

Composites during significant precipitation events have revealed the relationship between OPG, ABJ height, Fr, and the synoptic conditions. To emphasize these features, two cases are selected as representative high and low OPG conditions (Fig. 7). On 11 August 1987, a large OPG of $64 \mathrm{~mm} \mathrm{~km}^{-1}$ coexisted with an average ABJ height of $2780 \mathrm{~m} \mathrm{MSL}(728 \mathrm{hPa})$ and a mean Fr of 0.21 . Note that the low ABJ height and high Fr are consistent with a high OPG in Fig. 5. At this time a low-level cyclone is centered near $40^{\circ}-45^{\circ} \mathrm{S}$ and just off of the coast, having traveled zonally approximately $10^{\circ}$ over the previous $24 \mathrm{~h}$. The surface features are associated with an eastward-propagating, low-amplitude wave at $500 \mathrm{hPa}$. Even though the amplitude of the trough is relatively low, the high amount of shear vorticity at the base of the trough would significantly contribute to the vertical motion and height tendency. The strong, primarily zonal wind at $500 \mathrm{hPa}$ exists in a broad swath northward from the trough remaining essentially unchanged over the prior 2 days. This zonal flow band is only really perturbed by the shortwave on its poleward side, associated with the propagating surface cyclone.

A cross section along $30^{\circ} \mathrm{S}$ at the same time reveals the westward flow impinging on the topography and also the ABJ (Fig. 7e). Given the meridional temperature gradient (Fig. 7c), it is not surprising that the zonal flow increases rapidly with height. The large zonal wind contributes greatly to a high Fr that is common with high OPG events. The stability is also slightly less below $700 \mathrm{hPa}$ when compared to the second, lower Fr case, but differences in zonal wind seem to drive most of the variation in Fr. The core of the ABJ is located around $800 \mathrm{hPa}$ at this time, which falls well within the realm of what is considered to be a low ABJ. The largest upward vertical motion is above the $A B J$ and inland over the higher terrain elevations. Conversely, below and just west of the ABJ the flow is close to being stagnant, which corresponds to the small Fr at low levels.

A contrasting case occurred on 26 July 2004 and embodies the conditions with a small OPG of $2.3 \mathrm{~mm} \mathrm{~km}^{-1}$, an average ABJ height of $3710 \mathrm{~m}$ MSL $(650 \mathrm{hPa})$, and a mean Fr of 0.09. Examining the synoptic charts (Fig. 7) reveals clear differences from the preceding high OPG case. While a low-level cyclone is centered just offshore again, there is also an anticyclone to the west. Minimal movement of these features occurred in the previous $24 \mathrm{~h}$. Little vertical tilt of the system exists such that the center of the surface features is underneath the corresponding 500-hPa anomalies. The cutoff low depicted on the $500-\mathrm{hPa}$ surface extends all the way to $10^{\circ} \mathrm{S}$ and is a stark contrast to the wide swath of zonal flow of the previous case. These synoptic differences are consistent with the composite 500-hPa height anomalies for high and low OPG (Fig. 6).

The cross section at $30^{\circ} \mathrm{S}$ (Fig. 7f) reveals that the height of the $\mathrm{ABJ}$ at this time is at $600 \mathrm{hPa}$. Upward motion is occurring underneath the jet and is large above the lower elevations near the coast. There is subsidence occurring east of the jet core above the higher elevations $\left(70.5^{\circ} \mathrm{W}\right)$ that would contribute to a low OPG. The deep trough is associated with mainly meridional flow, but there is still a zonal component that impinges on the Andes Cordillera. The weaker zonal wind results in a lower Fr as well as slightly higher stability at the coast under $700 \mathrm{hPa}$ as compared to the previous case. Offshore toward the trough axis, the stability decreases in the lowest part of the atmosphere.

\section{e. Precipitation only at the coast or only at high elevations}

During most significant events, precipitation is recorded at every station along the valley. For some events most of the precipitation is concentrated at the coast, while for other events the precipitation is concentrated at high elevations. In fact, two storms produced precipitation only at La Laguna (i.e., the highest gauge at $3100 \mathrm{~m} \mathrm{MSL}$ ) with no precipitation at any other station and had total amounts of $63.5 \mathrm{~mm}(22 \%$ of the annual 1980 precipitation; see storm event 2 in Table 3 ) and $56 \mathrm{~mm}$ (44\% of the annual 2012 precipitation; see event 56 in Table 3). Two subsets of events were selected to investigate atmospheric conditions during storms that were concentrated at either the coast or at high altitudes. The first subset includes six cases with significant precipitation at the coastal station and no precipitation at the highest station. The second subset includes 12 cases with significant precipitation at the highest station and no precipitation at the coastal station (see boldface rows in Table 3). These storms will be referred to as "highland only" and "coast only" regardless of what happens at the other intermediate locations.

The ABJ is identified in five of the six coast-only cases using the reanalysis data; therefore, the sample size is considered insufficient to make any conclusions regarding the $\mathrm{ABJ}$. For the highland-only cases, the $\mathrm{ABJ}$ is present in 10 of the 12 cases, and the ABJ is on average $3270 \mathrm{~m}$ MSL. The ABJ height is only slightly above average, and there tends to be large variability in the OPG-ABJ height relationship, so again, few conclusions can be made about the role of $\mathrm{ABJ}$ height. 

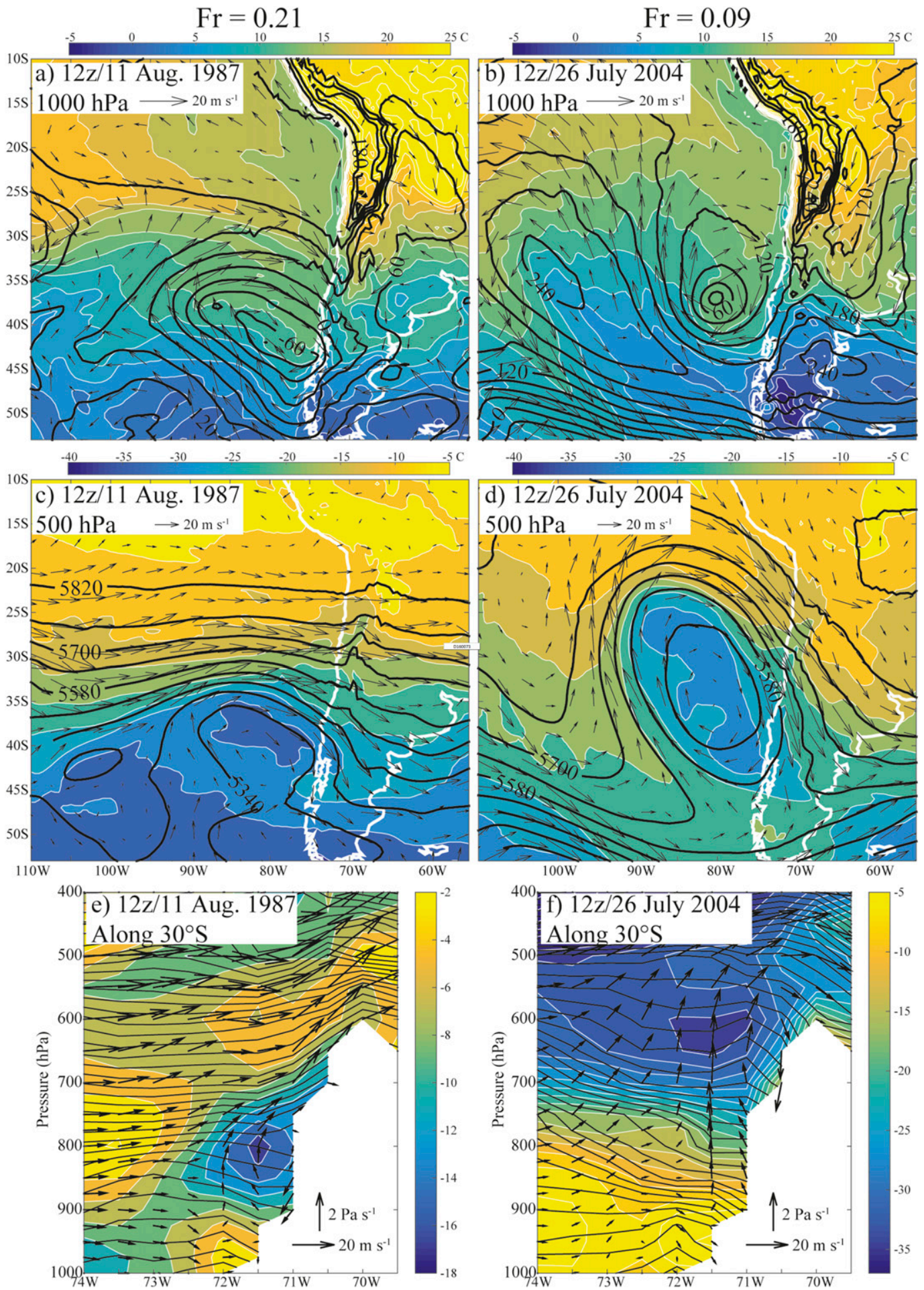

FIG. 7. Synoptic weather maps at 1200 UTC (left) 11 Aug 1987 and (right) 26 Jul 2004. (a),(b) 1000-hPa geopotential heights (gpm; contours), temperatures $\left({ }^{\circ} \mathrm{C}\right.$; color bars on top), and wind vectors (speed scale in the upper left). (c),(d) As in (a),(b), but for $500 \mathrm{hPa}$. (e),(f) Longitude-pressure cross sections along $30^{\circ} \mathrm{S}$ with potential temperatures (K; black contours), in-the-plane $(u, w)$ wind vectors (scales in the bottom right), and meridional wind components $\left(\mathrm{m} \mathrm{s}^{-1}\right.$; white contours and color bars). 

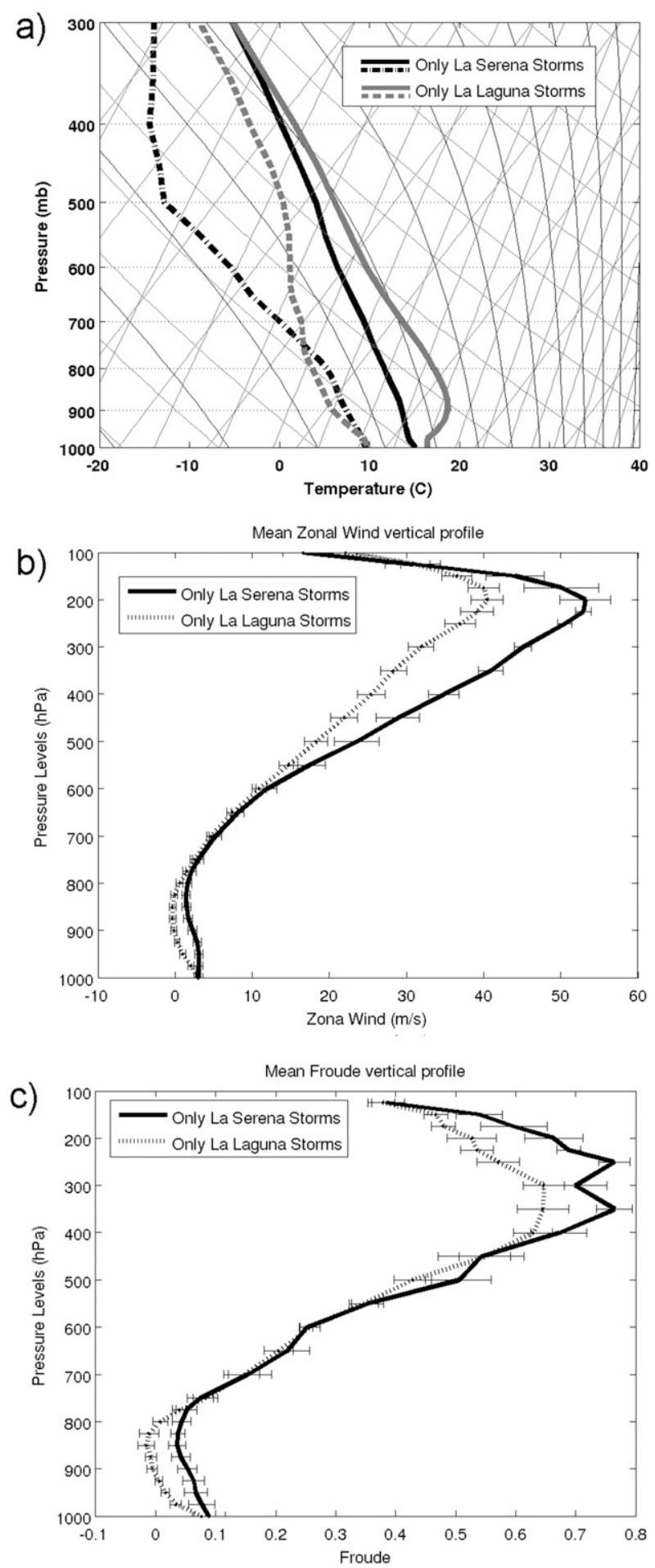

FIG. 8. Vertical profiles of the mean values of (a) air temperature, (b) zonal wind, and (c) Fr. The horizontal bars at all levels represent the standard error.

The Fr depends on the stability and zonal flow. To assess these characteristics during the coast-only or highland-only events, the vertical profiles of the mean temperature, mean zonal wind, and corresponding $\mathrm{Fr}$ are constructed just offshore at $29.5^{\circ} \mathrm{S}, 71.5^{\circ} \mathrm{W}$ (Fig. 8). Differences in the mean temperature between the two groups of events reveal that the temperature in the lower levels is warmer during the highland-only events, with the maximum temperature difference at about $900 \mathrm{hPa}$ and diminishing with height. The mean temperature profiles suggest that differences of stability between the lower and middle levels contribute to confining the precipitation at either upper or lower elevations. The mean lapse rate for coast-only events is fairly constant below $300 \mathrm{hPa}$. The mean lapse rate for highland-only events shows a slight temperature inversion below $900 \mathrm{hPa}$ and is noticeably less stable than the coast-only temperature profile above $900 \mathrm{hPa}$, which would favor upward motion at higher levels and suppress upward motion at lower elevations.

Another component in the calculation of $\mathrm{Fr}$ is the zonal wind (Fig. 8b). If the flow impinging on the topography is strong enough, it can overcome the stability that resists upward motion. Below $800 \mathrm{hPa}$, the zonal wind during coast-only events is slightly stronger than highland-only events. The lower stability and higher onshore wind results in an Fr that is larger than highland-only events, but only up to about $800 \mathrm{hPa}$ (Fig. 8c). In the 700-500-hPa layer, which is where the correlation between OPG and Fr has been shown, Fr does not show any clear difference between the two extreme events. For the highland-only events, below $800 \mathrm{hPa}$ the zonal wind is near zero and high stability exists, so that both contribute to a low Fr. Weaker zonal winds and stronger stability explain the suppression of precipitation at lower levels along the coast. The steeper midlevel lapse rate during the significant coast-only events suggests that the precipitation at higher elevations is related to the enhanced possibility of convection from the decreased stability, and the precipitation has less to do with large-scale orographic uplift. Examination of infrared satellite imagery during the highland-only events reveals that this is indeed what is occurring. There are typically high cloud tops, and the convection is mainly concentrated over the high elevations (and in some cases clear at the coast) that support this claim.

\section{Summary and discussion}

This study investigated the OPG estimated from a long-term observational record alongside reanalysis data to quantify and better understand how the precipitation varies with the elevation in the semiarid subtropical Andes. We have confirmed our initial hypothesis that Fr is able to discriminate between high and low OPG 


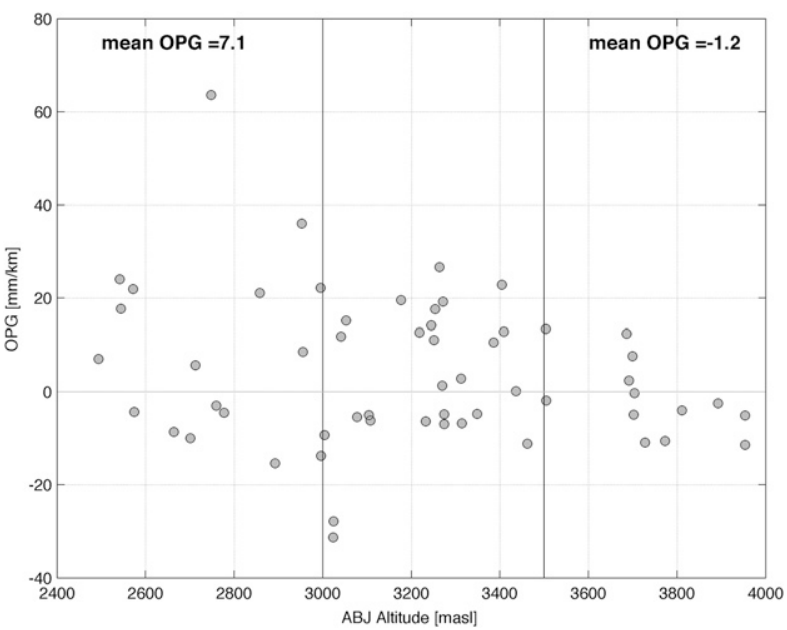

FIG. 9. Dispersion plot of the OPG and the ABJ altitude for all the storms with a clear ABJ. The displayed mean values in the upper part of the plot were calculated for all the ABJ height below $3000 \mathrm{~m}$ MSL (lhs) and above $3500 \mathrm{~m}$ MSL (rhs).

for observed significant rainfall events along the Elqui basin, similar to other regions.

The ABJ height also shows different mean values for the subsets of blocked and unblocked cases (the two groups defined by Fr thresholds); however, we could not find any statistically significant difference between the mean values for the two groups using the reanalysis dataset. The ABJ height could be more accurately studied using vertical wind profilers or higher-resolution mesoscale simulations. The relationship between the ABJ height from the CFSR and the observed OPG during the most significant events is provided in Fig. 9. On average, lower ABJ heights are associated with high OPG variance while the greatest OPGs show less variance and lower ABJ heights. As a result, the ABJ height cannot be used to discriminate between high and low OPGs. The ABJ is a typical feature during significant precipitation events, but even when present, the height of the ABJ is not as effective as Fr at discriminating high and low OPG cases.

One explanation is that the redistribution of the precipitation by the barrier jet is a nonlinear dynamical mechanism (Hughes et al. 2009; Smith 2003a). It can be inferred that in cases with a negative OPG, a plausible secondary circulation around the ABJ could help to explain the more even distribution of precipitation along the basin's main axis (east-west). Since the vertical wind shear across the mountain may be a key variable to identify the OPG variability (Neiman et al. 2010; Colle 2004; Lundquist et al. 2010), the height of the ABJ should affect it. A lower ABJ would have a positive vertical wind shear at the mountain slope that favors the forced ascent and thus positive OPGs (e.g., Colle 2004), while higher ABJs would be the opposite.
Significant events with high positive OPGs (high Fr) are typically brought about by an equatorward shift of the midlatitude storm tracks in connection with a blocking anticyclone over the Bellingshausen Sea (Rutllant and Fuenzalida 1991). Extreme positive OPG cases (i.e., precipitation mostly concentrated in the highlands) are often associated with a stable lower layer and a large meridional pressure gradient at $500 \mathrm{hPa}$ that supports strong zonal winds at the base of the trough. Extreme negative OPG cases (i.e., precipitation mostly concentrated at the coast) are often linked with the northern edge of a surface migratory cyclone, and the individual PV charts (not shown) frequently reveal an occluded low. In fact, the equatorward extension of the 500-hPa height anomalies is quite apparent in the composites. Details of these individual systems should be diagnosed with a highresolution regional model such as the Weather Research Forecasting Model (Skamarock et al. 2008), but the largescale features that were shown for the high and low OPG cases are fairly typical.

An additional feature of cold-air incursions into the subtropics is the frequent presence of a jet streak when the polar jet merges with the subtropical jet. For example, when the secondary ageostrophic circulation around the exit area of the jet streak approaches the mountain top, it would be related with upward/downward vertical motion and modify the OPGs. Both of the individual cases represent the key features determined from the composites. Since composites tend to show more diffuse features due to averaging over many events, examining individual cases provides a sharper depiction of the relevant variables. Of course, not all events strictly follow the generalizations acquired from the composite analysis like these cases, but both composites and the representative cases, including others not shown here, have generally consistent results.

Concerning the physical mechanisms proposed by Barrett et al. (2009) to explain the role of the Andes blocking in the precipitation distribution during a significant storm in central Chile, it seems that the altitude of the maximum northerly winds and associated moisture advection and convergence along the front differ significantly from what we have found $500 \mathrm{~km}$ farther north. However, it is possible that the observed slowdown in the northeastward front progression could play a role in explaining some of the atypical storms along the Elqui Valley as well as the advection of dry air in the central valley.

Finally, it is worth mentioning that the observed precipitation data at La Laguna is subject to a large uncertainty because of the frequent occurrence of solid precipitation at this elevation (e.g., bias because of snow undercatch during windy conditions) and the coarse 
method of measurement. Moreover, a limitation of our study is that the highest available gauge is located at $3100 \mathrm{~m}$ MSL, while the terrain elevation in the study area may exceed $6000 \mathrm{~m}$ MSL. About $40 \%$ of the catchment area is located above $3100 \mathrm{~m} \mathrm{MSL}$, and there was no systematic precipitation observation in this area until just recently. In the framework of the WMO Solid Precipitation Intercomparison Experiment (SPICE; http:// www.rap.ucar.edu/projects/SPICE/), a precipitation gauge was installed at $4300 \mathrm{~m}$ MSL near the Tapado glacier in 2013, which may help to better constrain the precipitation gradient in the future. Such efforts have been in progress not only in the Elqui Valley but also in adjacent basins (e.g., Limarí and Choapa Valley). In addition to this, direct wind profile measurements along the Andes west slope would be highly desirable to better assess detailed properties of the $\mathrm{ABJ}$ and its hypothesized secondary circulation. Further work may also include remotely sensed information, such as satellite-based precipitation or snow cover area products.

Acknowledgments. We want to acknowledge Jessica Lundquist and her research group for providing the wind profilers' data from La Sierra Nevada (HMT) led by the ESRL Physical Sciences Division and also for some fruitful discussions on the barrier jet secondary circulation idea during a short stay of L. Scaff in her group. This manuscript was initially developed as a part of the Master in Meteorology and Climatology program at the Department of Geophysics of the Universidad de Chile. Partial funding to RR and JAR was provided by FONDECYT Grant 1151125. We would also like to thank two anonymous reviewers for their constructive comments that considerably helped to improve the original manuscript.

\section{REFERENCES}

Austin, G. L., and K. N. Dirks, 2006: Topographic effects on precipitation. Encyclopedia of Hydrological Sciences, Part 3, Wiley, chapter 30, doi:10.1002/0470848944.hsa033.

Barahona, C., 2013: Precipitaciones asociadas a Bajas Segregadas en la zona central de Chile, entre los años 2003 y 2005. B.S. thesis, Departamento de Meteorología, Universidad de Valparaíso, $131 \mathrm{pp}$.

Barrett, B. S., R. Garreaud, and M. Falvey, 2009: Effect of the Andes Cordillera on precipitation from a midlatitude cold front. Mon. Wea. Rev., 137, 3092-3109, doi:10.1175/ 2009MWR2881.1.

, D. B. Krieger, and C. P. Barlow, 2011: Multiday circulation and precipitation climatology during winter rain events of differing intensities in central Chile. J. Hydrometeor., 12, 1071-1085, doi:10.1175/2011JHM1377.1.

Barry, R. G., 1992: Mountain climatology and past and potential future climatic changes in mountain regions: A review. Mt. Res. Dev., 12, 71-86, doi:10.2307/3673749.
Bourgin, P.-Y., V. Andreassian, S. Gascoin, and A. Valery, 2012: Que sait-on des précipitations en altitude dans les Andes semi-arides du Chili? Houille Blanche, 2, 12-17, doi:10.1051/ $\mathrm{lhb} / 2012010$.

Colle, B. A., 2004: Sensitivity of orographic precipitation to changing ambient conditions and terrain geometries: An idealized modeling perspective. J. Atmos. Sci., 61, 588-606, doi:10.1175/1520-0469(2004)061<0588:SOOPTC > 2.0.CO;2.

Daly, C., R. Neilson, and D. Phillips, 1994: A statisticaltopographic model for mapping climatological precipitation over mountainous terrain. J. Appl. Meteor., 33, 140-158, doi:10.1175/1520-0450(1994)033<0140:ASTMFM>2.0.CO;2.

Durran, D. R., and J. B. Klemp, 1982: On the effects of moisture on the Brunt-Väisälä frequency. J. Atmos. Sci., 39, 2152-2158, doi:10.1175/1520-0469(1982)039<2152:OTEOMO>2.0.CO;2.

Escobar, F., and P. Aceituno, 1998: Influencia del fenómeno ENSO sobre la precipitación nival en el sector Andino de Chile central durante el invierno. Bull. Inst. Fr. Etud. Andines, 27, 753-759.

Falvey, M., and R. Garreaud, 2007: Wintertime precipitation episodes in central Chile: Associated meteorological conditions and orographic influences. J. Hydrometeor., 8, 171-193, doi:10.1175/JHM562.1.

Favier, V., M. Falvey, A. Rabatel, E. Praderio, and D. López, 2009: Interpreting discrepancies between discharge and precipitation in high-altitude area of Chile's Norte Chico region $\left(26^{\circ}-32^{\circ} \mathrm{S}\right)$. Water Resour. Res., 45, W02424, doi:10.1029/ 2008WR006802.

Fuenzalida, H., R. Sanchez, and R. Garreaud, 2005: A climatology of cutoff lows in the Southern Hemisphere. J. Geophys. Res., 110, D18101, doi:10.1029/2005JD005934.

Garreaud, R., 2013: Warm winter storms in central Chile. J. Hydrometeor., 14, 1515-1534, doi:10.1175/JHM-D-12-0135.1.

— , and H. A. Fuenzalida, 2007: The influence of the Andes on cutoff lows: A modeling study. Mon. Wea. Rev., 135, 15961613, doi:10.1175/MWR3350.1.

Gascoin, S., S. Lhermitte, C. Kinnard, K. Borstel, and G. E. Liston, 2013: Wind effects on snow cover in Pascua-Lama, dry Andes of Chile. Adv. Water Resour., 55, 25-39, doi:10.1016/ j.advwatres.2012.11.013.

Houze, R. A., 2012: Orographic effects on precipitating clouds. Rev. Geophys., 50, 1-47, doi:10.1029/2011RG000365.

Hughes, M., A. Hall, and R. G. Fovell, 2009: Blocking in areas of complex topography, and its influence on rainfall distribution. J. Atmos. Sci., 66, 508-518, doi:10.1175/2008JAS2689.1.

Juliá, C., D. Rahn, and J. A. Rutllant, 2012: Assessing the influence of the MJO on strong precipitation events in subtropical, semiarid north-central Chile $\left(30^{\circ} \mathrm{S}\right)$. J. Climate, 25, 7003-7013, doi:10.1175/JCLI-D-11-00679.1.

Kalthoff, N. K., and Coauthors, 2002: Mesoscale wind regimes in Chile at $30^{\circ}$ S. J. Appl. Meteor., 41, 953-970, doi:10.1175/ 1520-0450(2002)041<0953:MWRICA>2.0.CO;2.

Lundquist, J. D., J. R. Minder, P. J. Neiman, and E. Sukovich, 2010: Relationships between barrier jet heights, orographic precipitation gradients, and streamflow in the northern Sierra Nevada. J. Hydrometeor., 11, 1141-1156, doi:10.1175/ 2010JHM1264.1.

Masiokas, M. H., R. Villalba, B. H. Luckman, C. Le Quesne, J. C. Aravena, C. D. E. Cuaternarios, and P. Arenas, 2006: Snowpack variations in the central Andes of Argentina and Chile, 1951-2005: Large-scale atmospheric influences and implications for water resources in the region. J. Climate, 19, 63346352, doi:10.1175/JCLI3969.1. 
Mass, C. F., D. Ovens, W. Ken, B. A. Colle, K. Westrick, and B. A. Colle, 2002: Does increasing horizontal resolution produce more skillful forecasts? Bull. Amer. Meteor. Soc., 83, 407-430, doi:10.1175/1520-0477(2002)083<0407: DIHRPM $>2.3 . \mathrm{CO} ; 2$.

Neiman, P. J., E. M. Sukovich, F. M. Ralph, and M. Hughes, 2010: A seven-year wind profiler-based climatology of the windward barrier jet along California's northern Sierra Nevada. Mon Wea. Rev., 138, 1206-1233, doi:10.1175/2009MWR3170.1.

Parish, T. R., 1982: Barrier winds along the Sierra Nevada mountains. J. Appl. Meteor., 21, 925-930, doi:10.1175/ 1520-0450(1982)021<0925:BWATSN>2.0.CO;2.

Renwick, J. A., and M. J. Revell, 1999: Blocking over the South Pacific and Rossby wave propagation. Mon. Wea. Rev., 127, 2233-2247, doi:10.1175/1520-0493(1999)127<2233:BOTSPA>2.0.CO;2.

Roe, G. H., 2005: Orographic precipitation. Annu. Rev. Earth Planet. Sci., 33, 645-671, doi:10.1146/annurev.earth.33.092203.122541.

Rondanelli, R., L. Gallardo, and R. D. Garreaud, 2002: Rapid changes in ozone mixing ratios at Cerro Tololo $\left(30^{\circ} 10^{\prime} \mathrm{S}\right.$, $70^{\circ} 48^{\prime} \mathrm{W}, 2200 \mathrm{~m}$ ) in connection with cutoff lows and deep troughs. J. Geophys. Res., 107, 4677, doi:10.1029/ 2001JD001334.

Rotunno, R., and R. A. Houze, 2007: Lessons on orographic precipitation from the Mesoscale Alpine Programme. Quart. J. Roy. Meteor. Soc., 133, 811-830, doi:10.1002/qj.67.

Rutllant, J. A., 1983: Vientos de barrera en los Andes de Chile Central. Jornadas Nacionales de Física 1983, Frontera, 4952 .

and H. Fuenzalida, 1991: Synoptic aspects of the central Chile rainfall variability associated with the Southern Oscillation. Int J. Climatol., 11, 63-76, doi:10.1002/joc.3370110105.
Saha, S., and Coauthors, 2010: The NCEP Climate Forecast System Reanalysis. Bull. Amer. Meteor. Soc., 91, 1015-1057, doi:10.1175/ 2010BAMS3001.1.

Skamarock, W. C., and Coauthors, 2008: A description of the Advanced Research WRF version 3. NCAR Tech. Note NCAR/TN-475+STR, 113 pp., doi:10.5065/D68S4MVH.

Smith, R. B., 2003a: A linear upslope-time-delay model for orographic precipitation. J. Hydrol., 282, 2-9, doi:10.1016/ S0022-1694(03)00248-8.

Souvignet, M., and J. Heinrich, 2011: Statistical downscaling in the arid central Andes: Uncertainty analysis of multi-model simulated temperature and precipitation. Theor. Appl. Climatol., 106, 229-244, doi:10.1007/s00704-011-0430-z.

Valéry, A., V. Andréassian, and C. Perrin, 2010: Regionalization of precipitation and air temperature over high-altitude catchmentsLearning from outliers. Hydrol. Sci. J., 55, 928-940, doi:10.1080/ 02626667.2010 .504676 .

Viale, M., and M. N. Nuñez, 2011: Climatology of winter orographic precipitation over the subtropical central Andes and associated synoptic and regional characteristics. J. Hydrometeor., 12, 481-507, doi:10.1175/2010JHM1284.1.

Viviroli, D., and R. Weingartner, 2004: The hydrological significance of mountains: From regional to global scale. Hydrol. Earth Syst. Sci., 8, 1017-1030, doi:10.5194/hess-8-1017-2004.

- , H. H. Dürr, B. Messerli, M. Meybeck, and R. Weingartner, 2007: Mountains of the world, water towers for humanity: Typology, mapping, and global significance. Water Resour. Res., 43, W07447, doi:10.1029/2006WR005653.

Wallace, J. M., and P. V. Hobbs, 2006: Atmospheric Science: An Introductory Survey. 2nd ed. International Geophysical Series, Vol. 92, Academic Press, 504 pp. 